\title{
Influence of socio-economic indicators and territorial networks at the spatiotemporal spread dynamics of Covid-19 in Brazil
}

\author{
Miguel da Guia Albuquerque ${ }^{1}$ \\ Jefferson Rodrigues dos Santos ${ }^{2}$ \\ Angelita Fialho Silveira ${ }^{3}$ \\ Dardo Lorenzo Bornia Junior ${ }^{4}$ \\ Rozele Borges Nunes ${ }^{5}$ \\ Tiago Borges Ribeiro Gandra ${ }^{6}$ \\ André Luis Corrêa da Silva ${ }^{7}$ \\ Gustavo Borba de Miranda ${ }^{8}$ \\ Alessandra Ruiz Trevisol ${ }^{9}$
}

Keywords:

Coronavirus

SARS CoV-2

Pandemic in Brazil Social vulnerability

\begin{abstract}
This work aims to provide an overview of the territorial evolution of COVID-19 (SARS-CoV-2) in Brazil using socio-demographic variables, for the time span between February 26, 2020 until January 24, 2021. Socio-demographic indicators, basic sanitation infrastructure data, and epidemiological bulletins were integrated using Principal Components Analysis (PCA) to develop a social vulnerability index (SVI), to estimate the degree of exposure risk of the Brazilian population to COVID19. The results indicate that the majority of confirmed cases were reported from the main Brazilian capitals, linked to well-developed port and airport modes. In terms of deaths, the states of São Paulo, Rio de Janeiro, Ceará and Pernambuco were at the top of the ranking. On the contrary, there were some states of the midwest (Mato Grosso do Sul) and the north (Acre, Amapá, Roraima, Rondônia and Tocantins), that recorded low mortality indexes. The SVI reveals that the states of the north and north-east are the most vulnerable. Regarding the metropolitan areas, it was observed that the main capitals of the north and north-east, with the exception of Salvador, present significantly more critical numbers in terms of dissemination and deaths by COVID-19 than the capitals of the south-southeast, where the SVI is lower. The comparative exception was Santa Catarina state metropolitan areas. Finally, as the virus does not strike everyone in the same way, one of the great challenges is to search for solutions to cope with COVID-19 in the face of very unequal realities. Thus, a reflection on the strategies adopted by the Brazilian government is relevant, while considering the continental dimensions and the diversity of the Brazilian regions, to obtain a better analysis of the more vulnerable populations and social groups.
\end{abstract}

\footnotetext{
1 Instituto Federal de Educação, Ciência e Tecnologia do Rio Grande do Sul - IFRS, Rio Grande, RS, Brasil. migueldaguia@gmail.com

2 IFRS, Rio Grande, RS, Brasil.jefferson.santos@riogrande.ifrs.edu.br

${ }^{3}$ IFRS, Rio Grande, RS, Brasil. angelita.silveira@riogrande.ifrs.edu.br

${ }^{4}$ IFRS, Rio Grande, RS, Brasil. dardo.bornia@riogrande.ifrs.edu.br

${ }^{5}$ IFRS, Rio Grande, RS, Brasil.rozele.nunes@riogrande.ifrs.edu.br

${ }^{6}$ IFRS, Rio Grande, RS, Brasil. tiago.gandra@riogrande.ifrs.edu.br

${ }^{7}$ IFRS, Rio Grande, RS, Brasil. andre.silva@riogrande.ifrs.edu.br

${ }^{8}$ IFRS, Rio Grande, RS, Brasil. gustavo.miranda@riogrande.ifrs.edu.br

${ }^{9}$ IFRS, Rio Grande, RS, Brasil.alessandra.trevisol@riogrande.ifrs.edu.br
} 


\section{INTRODUCTION}

COVID-19 is a highly pathogenic viral infection caused by the SARS-CoV-2 virus (HAMID; MIR; ROHELA, 2020) . Data from the World Health Organization (WHO, 2021) have revealed that, as of January 24, 2021, there were more than 98 million confirmed cases and more than 2 million deaths related to COVID-19. The first cases were reported in the city of Wuhan, China in December, 2019. On January 30, 2020, WHO stated that the COVID-19 outbreak in this country was a public health emergency of international interest, presenting a high risk for countries with vulnerable health systems (SOHRABI et al., 2020).

In Brazil, the first case of COVID-19, according to (RODRIGUEZ-MORALES et al., 2020), was confirmed on February 25, 2020 in the city of São Paulo. The self-declared travel history and subsequent genetic analyses confirmed, according (CANDIDO et al., 2020), that the first detected infection was acquired via importation of the virus from Northern Italy. The figures in the country, until January 24, 2021, exceeded 8.8 million confirmed cases and 217 thousand deaths (DATASUS, 2021). Within this context, the present work aims to outline a panorama of the socio-territorial dynamics of COVID-19 in Brazil, between February 26, 2020 and January 24, 2021, seeking to correlate transmissibility with issues of mobility, basic infrastructure, and socioeconomic conditions.

Risk and social vulnerabilities in the Brazilian context of coping with COVID-19

Health phenomena are determined by factors such as behavioral relations and interactions between individuals, and these with their natural, social and economic environments (SOURIS, 2019). The articulation between the territory and different social markers is a crucial analytic tool in the production of population health standard (SANTOS, 2020). When analyzing situations of exposure risks and vulnerabilities related to COVID-19, it is necessary to consider the multiple dimensions that constitute the lives of the people. The Brazilian spatial formation is a historical product of social relations (BERNARDES; ARRUZZO; MONTEIRO, 2020), and its contradictions materialize in regional disparities in the intensity of economic flows, circulation structures, urban networks, forms and public health facilities.
From the perspective of a spatial analysis of risk and social vulnerability markers, a simple cartographic representation indicates that, rather frequently, health conditions and medical practices are not randomly distributed on the territory (SOURIS, 2019). .An overview on the populations in a vulnerable situation implies the need to identify that these subjects have diverse demands and needs, in addition to being susceptible to a risk that comes from living in a context of social inequality and injustice (DO CARMO; GUIZARDI, 2018). From this perspective, social vulnerability can be understood as the level of exposure a specific community has to certain risks (FATEMI et al., 2017), considering specific characteristics of the individual, its social aspects, and socio-economic relations (TAVARES et al., 2018). Social risk, according to Reis et al. (2014), constitutes a discriminating instrument, with different objective probabilities of damaging certain individuals, families and social groups.

Epidemic diseases have a structural impact on the social, political, and scientific context of a community. Air and maritime transport systems have been involved in the spread of diseases around the world, such as measles, influenza and coronavirus (BROWNE et al., 2016). In Brazil, ports and airports are the first and main entrances for commerce and tourism. Throughout the history of Brazil and the development of the relations between both ports and airports with the cities, epidemic diseases revealed a very variable, but growing dissemination flow.

The spatial analysis of the coronavirus spread can provide an important tool for the management of public health, showing the routes of disease dispersion and the fragility of the municipalities concerning their sociodemographic characteristics (GUIMARÃES et al., 2020). In the case of COVID-19, Silveira et al. (2020) have highlighted that in countries like Brazil, its dissemination occurred mainly through commercial passenger aviation, following primarily the configuration and logic of the urban hierarchy networks, transport and the population arrangement of cities.

The spread of the virus followed an urban hierarchy, as it first reached São Paulo and Rio de Janeiro, considered the main metropolises in the country. Subsequently, COVID-19 accelerated in the capitals, medium and small cities. Figure 1 presents a temporal evolution overview of COVID-19 incidence in the Brazilian territory. 
Figure 1 - Evolution of COVID-19 transmissibility in Brazil, between March 15, 2020 and January 15, 2021.
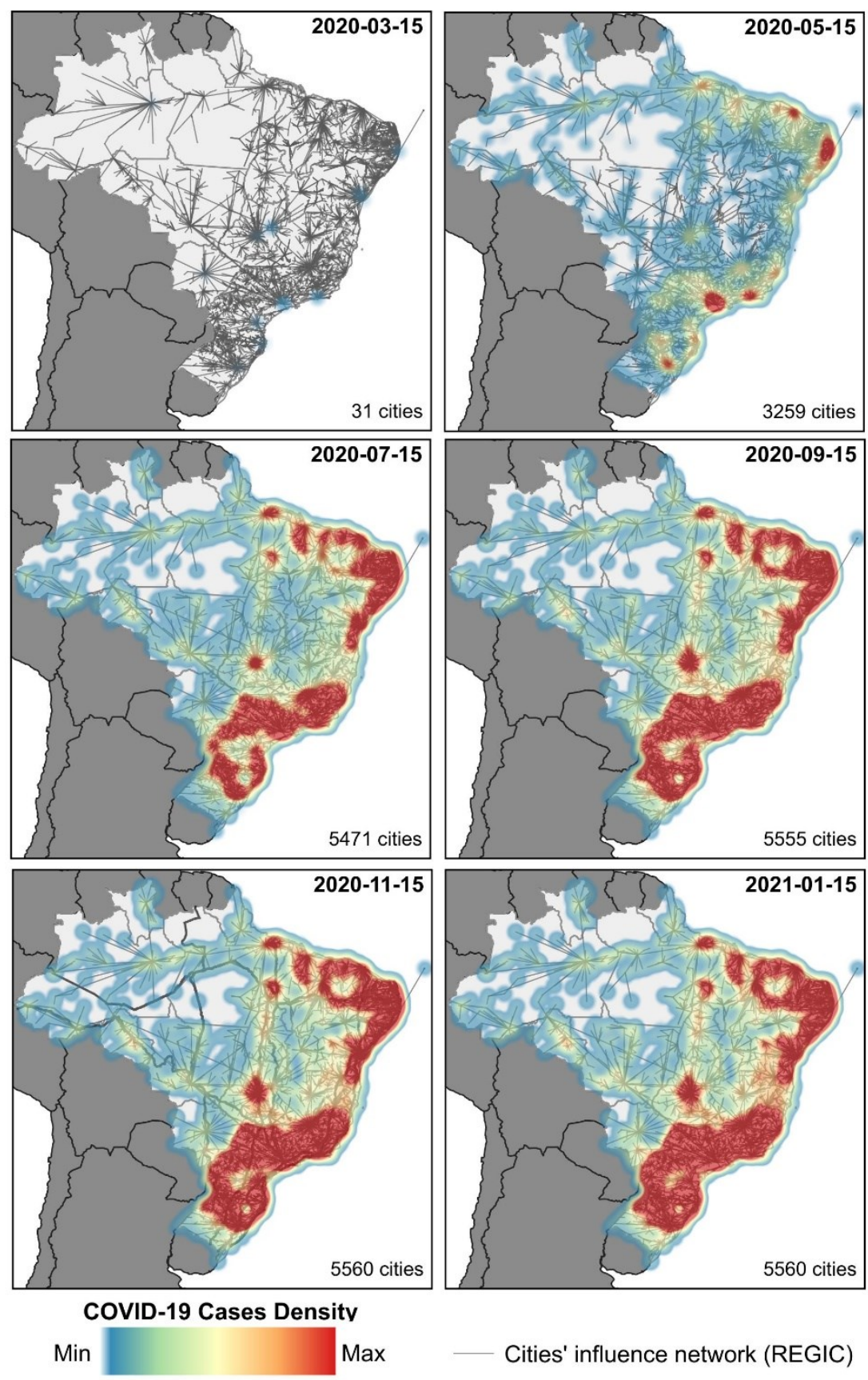

Cities' influence network (REGIC)

Source: The authors.

The propagation of COVID-19 is linked to circulation and connectivity between different Brazilian cities, reproducing the disjointed hierarchy of the relationship arrangements and the centrality exercised by large urban centers. A primary probe over the pandemic situation in Brazil leads directly to the issue of international borders. Restriction measures for the disembarkation of crews were partially adopted, as well as for the entrance of foreigners through dry borders, airports, and ports. However, restricting the entry of nationals into Brazilian territory was not started initially.

Among the main strategies adopted to minimize the consequences generated by the coronavirus are social isolation and distancing, the expansion of health services, economic, and political actions to support citizens and companies. However, the lack of infrastructure in regions located further away from the 
capitals and the social conditions of its inhabitants can cause difficulties in containing the virus and in its treatment, increasing the number of deaths. Therefore this study describes the COVID-19 in Brazil and assesses its evolution and relationship in the urban hierarchical structure of cities and social vulnerability, proposing a simple Social Vulnerability Index (SVI) based on multivariate statistics.

\section{MATERIALS AND METHODS}

\section{Data Gathering}

\section{COVID-19 data}

Data for the evolution of COVID-19 in Brazil were extracted from the Epidemiological Bulletins provided by the State Health Secretariats and compiled on the brasil.io platform, with daily information on the number of cases and deaths, assembled by municipality. For some of the cases and deaths, the name of the municipality was not informed in the bulletins and were, therefore, filtered and discarded.

The data set used in this study covers the time span between the first confirmed case in Brazil (February 26, 2020) and January 24, 2021. Epidemic start dates (Day 0) were calculated using the date when the number of cases was greater than 100 (for states), and greater than 20 (for municipalities). Epidemiological days and weeks were counted starting from that date.

\section{Sociodemographic and infrastructure data}

Indicators of economic, social and sanitation characteristics were calculated from variables obtained in the last demographic census (2010) conducted by the Instituto Brasileiro de Geografia e Estatística - IBGE (IBGE, 2010), and assembled by census sectors. IBGE data were also used to define the Regiões de Influência das Cidades - REGIC (REGIC, 2018). Data for infrastructure and health were obtained from the Ministry of Health database (DataSUS), and the selected variables were grouped at the municipality level (Table. 2).

Table 2 - Socioeconomic and basic structure indicators used to perform the PCA. Source: The authors.

\begin{tabular}{|c|c|c|c|c|}
\hline Class & Indicator & Unity & Short Name & Font \\
\hline \multirow{4}{*}{$\begin{array}{c}\text { Basic } \\
\text { Infrastructure }\end{array}$} & Water supply & \multirow{4}{*}{$\begin{array}{l}\% \text { of the } \\
\text { residences }\end{array}$} & water_inadequacy & \multirow{4}{*}{ IBGE (2010) } \\
\hline & $\begin{array}{l}\text { Residence with } \\
\text { bathroom }\end{array}$ & & bathroom & \\
\hline & Garbage collection & & garbage & \\
\hline & Electricity supply & & eletric_energy & \\
\hline \multirow{8}{*}{$\begin{array}{l}\text { Employment } \\
\text { and Income } \\
\text { Conditions }\end{array}$} & Unemployment & $\%$ of the & unemployment & \multirow{4}{*}{ IBGE (2010) } \\
\hline & Informal workers & $\begin{array}{l}\text { (18 to } 65 \\
\text { years old) }\end{array}$ & informal_workers & \\
\hline & $\begin{array}{l}\text { People in extreme } \\
\text { poverty situation }\end{array}$ & \multirow{2}{*}{$\begin{array}{r}\% \text { of the } \\
\text { population }\end{array}$} & ext_poor & \\
\hline & $\begin{array}{l}\text { People in poverty } \\
\text { situation }\end{array}$ & & poor & \\
\hline & Average HDI & \multirow{4}{*}{ Index } & HDI_m & \multirow{4}{*}{ IPEA (2015) } \\
\hline & HDI Education & & HDI_educat & \\
\hline & HDI Longevity & & HDI_longev & \\
\hline & HDI Income & & HDI_income & \\
\hline
\end{tabular}

Source: The authors 
Socioeconomic indicators for data processing

The indicators, selected to describe municipalities according to basic household infrastructure and to income/employment conditions, were normalized and rescheduled for dimensionality-reduction through Principal Components Analysis (PCA). PCA is a multivariate technique that analyzes a data table representing observations described by several dependent variables, which are, in general, inter-correlated (ABDI; WILLIAMS, 2010). Its goal is to extract the important information from the data and to express this information as a set of new variables called principal components. One of the advantages of PCA is that it has no normality assumption. Using PCA, it was possible to compress $70 \%$ of the variance of the 12 indicators in the first component (Figure 2). Therefore, PC1 was used as a socioeconomic index for further analyses and comparison with data on the evolution of the epidemic in Brazil.

Figure 2 - The contribution of socio-economic indicators to the first two components, after the transformation by PCA.

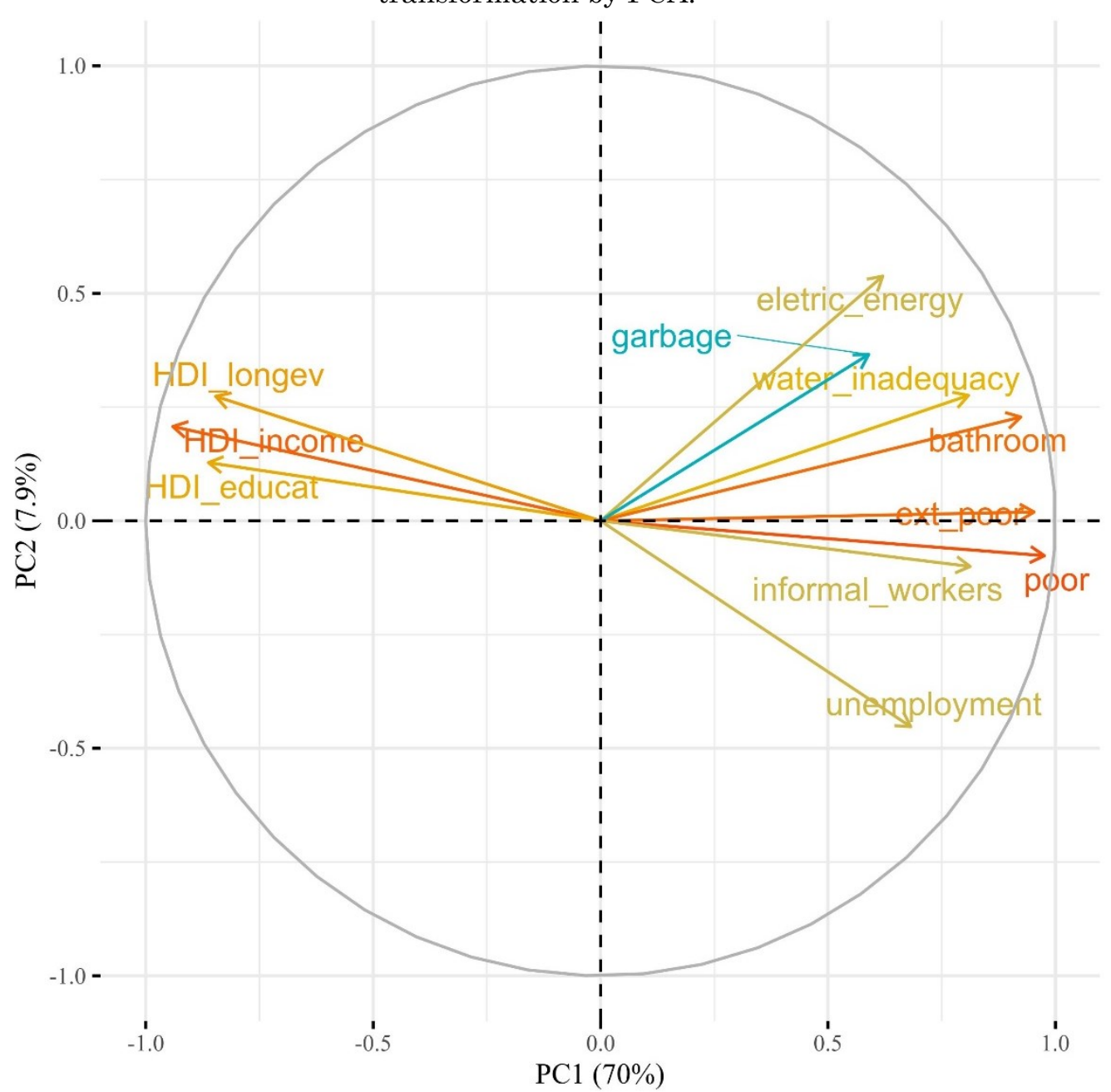

Source: The authors.

\section{RESULTS AND DISCUSSION}

The role of territorial networks in understanding the space dynamics of COVID-19

The concept of territory used here will be that given from the perspective of hybridity, as proposed by Santos (2005). This considers the legal-political dimensions and the state territory in its different federative circumscriptions (Union, state and municipalities), but also as a dynamic and scalable set of fixed and flows, in the forms and functions determined by the current mode of production, by the regional division labor and the insertion of the country in the globalized 
international system. In this perspective, COVID-19 transmissibility data in the Brazilian territory set a relationship between dynamism and economic synergies when compared to the number of cases, which reinforces the role of mobility, especially for people (Figure 3). Population mobility is associated with shifts in the workforce, the flux of assets and services, the mobility of managers in financial and productive activity and the phenomenon of tourism and leisure, associated with various social and income groups. Such movements, of different natures, also vary in terms of spatial and temporal scales. Kraemer et al. (2020) highlight that human mobility predicts the expansion and size of epidemics. In the case of Brazil, the mobility that crosses the national territory can be divided into three distinct and complementary networks, which are, a) movements generated by the international fluxes of a globalized economy, b) movements related to urban networks at different scales of regional integration, and c) movements related to the process of metropolization and the dynamics of metropolitan regions.

Figure 3 - Correlation between the density of COVID-19 and the main territorial networks in Brazil.

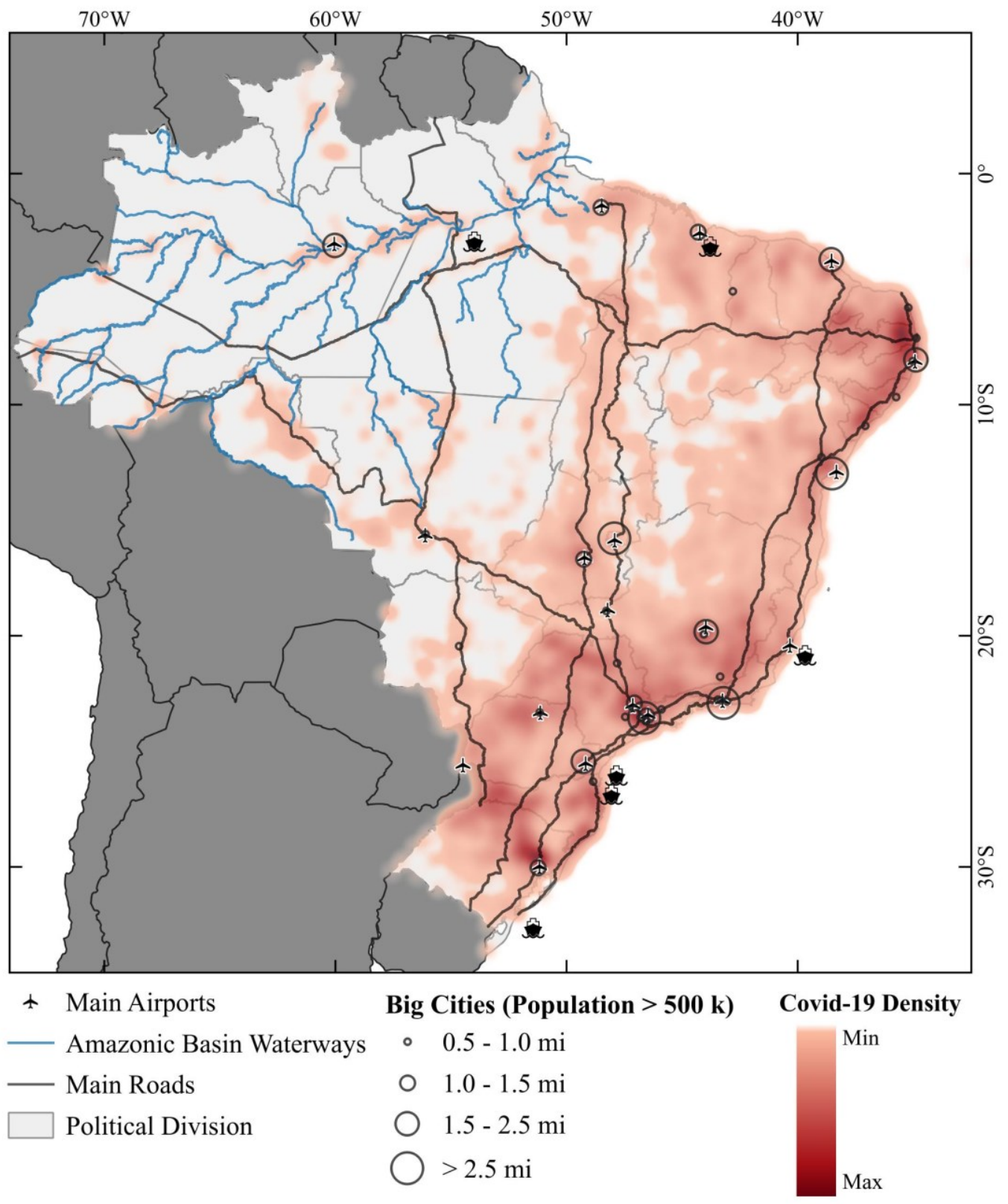

Source: The authors. 
The Brazilian Atlantic façade assumes the role of commanding the regional urban networks responsible for draining export production, and for receiving imported manufactured goods, accentuating the role of port cities as a hub connecting productive hinterlands with the world. This explains their roles as industrial and political command centers of the territory, positioning themselves at high levels of the national urban hierarchy, adding the administrative function as a factor of flows and population centralization. Thus, Brazilian port cities are characterized by the disembarkation of tourists, the movement of people linked to customs clearance, and the connection of the sea and land modals, whether railways or highways, responsible for internalization of flows. The exception to the primacy of the terrestrial modal occurs in the north of the country, where the cities of Manaus and Belém represent the connection between sea and air modes to the waterway network that represents the main connection between the populations of the Amazonian interior with such urban centers. The mapping and analysis of COVID-19 conducted by Guimarães et al. (2020) shows that its evolution is closely associated with these territorial structures which are fixed forms associated with the flows formed by them. The presence of federal and state road networks can be taken as indicators of contamination risk. In the first level of analysis, its distribution already reveals an inequality in terms of the coverage of the national territory. In Amazonas, the river axes are identified as the main diffusers of COVID-19, since the number of trips and river mobility was the variable that presented the highest correlation with disease progression (ALEIXO et al., 2020).
According to Browne et al. (2016), a investigation into the COVID-19 introduction in geographically distinct areas, through different hubs, provides more complete understanding of the transports system functions. In some regions of Brazil, the evolution of the forms of transport for energy, matter and information relativizes the historical locational factors of production. The Brazilian mid-western region represents the materialization of this change, being a region of late occupation in the formation of the Brazilian territory (MOREIRA, 2014). In the last decades, the region has intensified its connection with the globalized economy, based on its role on offering agricultural commodities, especially soy-beans and meat, connected to the main ports from the north to the south of Brazil, by road, rail, and waterway modes.

Regarding data from the Regiões de Influência das Cidades - REGIC (REGIC, 2018), category 1A (São Paulo) is characterized as being the great national metropolis, and $1 \mathrm{~B}$ (Rio de Janeiro), for national metropolises. In Figure 4 , both classes have medians that indicate worse conditions for the number of cases and deaths by COVID-19. Category $1 \mathrm{C}$ is classified as a metropolis, and comprises a set of 12 cities spread across the five Brazilian regions. These cities are characterized by a high number of cases and deaths. The diversity of values in both cases and deaths is explained by the different regional situations that characterize urban centers belonging to category $1 \mathrm{C}$, especially the urban centers' diversity of intermediate hierarchy, which act both in the daily role of attracting flows (agglomeration factor) and, therefore, contagion, as well as in the effort to provide medical care to those contaminated.

Figure 4 - Number of cases and deaths by COVID-19, per 100 thousand inhabitants, based on the hierarchical position of Brazilian urban centers.


Source: The authors. 
Categories 2 and 3 include regional capitals and sub-regional centers, respectively. Category 4 refers to zone centers, and category 5 includes local urban centers. Regarding the category 5 outliers, although data are consistent in terms of hierarchy, the occurrence of high indicators can be related to local urban centers, which represent nodes of globalized networks. These locations are characterized by border areas, dry ports, areas with industrial concentration such as packing plants and slaughterhouses, as well as local centers that are part of metropolitan regions, characterized by intense synergy with the metropolises and their characteristic commuting fluxes.

The REGIC data aims to capture the importance of urban centers, based on the command functions of business and public activities and the complexity of the commercial and service practices. The result is the hierarchical definition of urban centers and the delimitation of their regions of influence based on the identified material and immaterial flows. Urban centers of category 1 represented the priority locus for the occurrence of COVID-19 cases and deaths in Brazil. This group was characterized with high population concentrations and dynamics of multi-scale contacts (movements of globalization, regional economy, and metropolitan commuting movements).

\section{Progression of COVID-19 through Brazilian states}

Regarding the confirmed cases of COVID-19 (Figure 5), starting from the date of the 100th notified case, the state of São Paulo (SP) has demonstrated an increasing curve in the number of notified cases and deaths, with slight fluctuations of 150 days in the data series. Subsequently, the number of notifications displayed a slight fluctuation of 50 days, once again indicating growth between the final 200 and 300 days of the series. The state of Rio de Janeiro (RJ) revealed a similar pattern of growth in the first 100 days, where small fluctuations were found between days 100 and 250 of the monitoring. The vast majority of states revealed increasing curves, with the exception of the states of Paraná (PR) between the first 50 to 100 days; Mato Grosso do Sul (MS), where in the first 100 days the growth trend in the number of the cases was below the national average; and Acre (AC), which presented an intense growth in the first 50 days, losing the growth rhythm rate of the curve until the $100^{\text {th }}$ day, and being below the national average in the number of cases from the $100^{\text {th }}$ day of the data series.

Figure 5 - Evolution of the number of cases by Federative Units in Brazil.

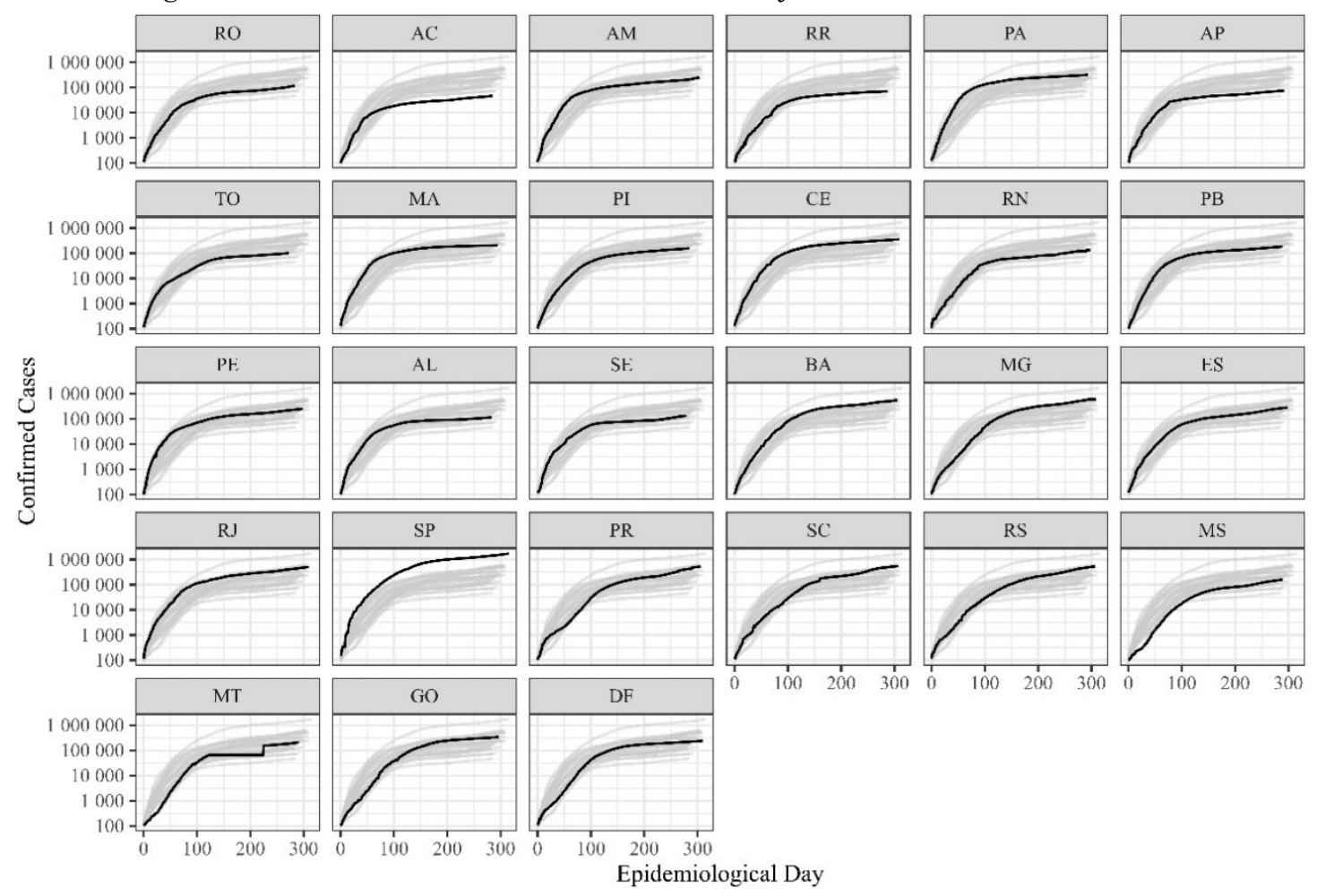

Source: The authors. 
On March 16, 2020 a state of emergency was declared by the Ministry of Health of Brazil, and subsequently April 28, 2020 was the milestone when Brazil overtook China on number of people infected by the new coronavirus. A phylogenetic network analysis, carried out by Forster et al. (2020) in 160 complete genomes of SARS-CoV-2, revealed the existence of three central variants (A, B, and $\mathrm{C}$ ). Type $\mathrm{C}$ is the main European type, with representatives in Brazil, California (USA), France, Italy, England and in Sweden (FORSTER et al., 2020).

The first confirmed cases of COVID-19 occurred in the main capitals of Brazil linked to well-developed port and airport modes. Data from the Ministry of Tourism of Brazil (MTUR, 2019) highlighted that, from 1989 to 2019, air transportation was responsible for the bulk of the flux of tourists from Europe, when compared to maritime transportation. Regarding the airports, the main routes to Europe depart from the states of São Paulo (Guarulhos and Congonhas airports), Rio de Janeiro (Galeão airport), Brasília, Porto Alegre, and Curitiba. In the northeast, the states of Ceará, Pernambuco and Bahia are the main tourist entrances.
Among the ten main source countries of tourists in Brazil, 50\% are European: France, Germany, Italy, Portugal, and the United Kingdom. The MTUR (2019) data and a study conducted by Jesus et al. (2020), about COVID-19 phylogeny, corroborate with the list of European nations listed by Forster et al. (2020).

Regarding the cases of confirmed deaths by COVID-19 (Figure 6), the states of São Paulo (SP), Rio de Janeiro (RJ), Ceará (CE) and Pernambuco (PE) are at the top of the ranking. At the opposite extreme, the states of the midwestern region (MS) and the north region (AC, $\mathrm{AP}, \mathrm{RO}, \mathrm{RR}, \mathrm{TO}$ ) exhibit low mortality rates for the data series. These results can be explained by the fact that these regions are not part of the main connection networks between the country's major metropolises. Given the largescale agricultural activity model (aimed at export), the regional dynamics is characterized by a low level of internal synergy, with a less developed urban network. This fact causes both the percentage of transmissibility and the percentage of death to increase later, when compared to large metropolises.

Figure 6 - Evolution of the number of deaths by Federative Units in Brazil.

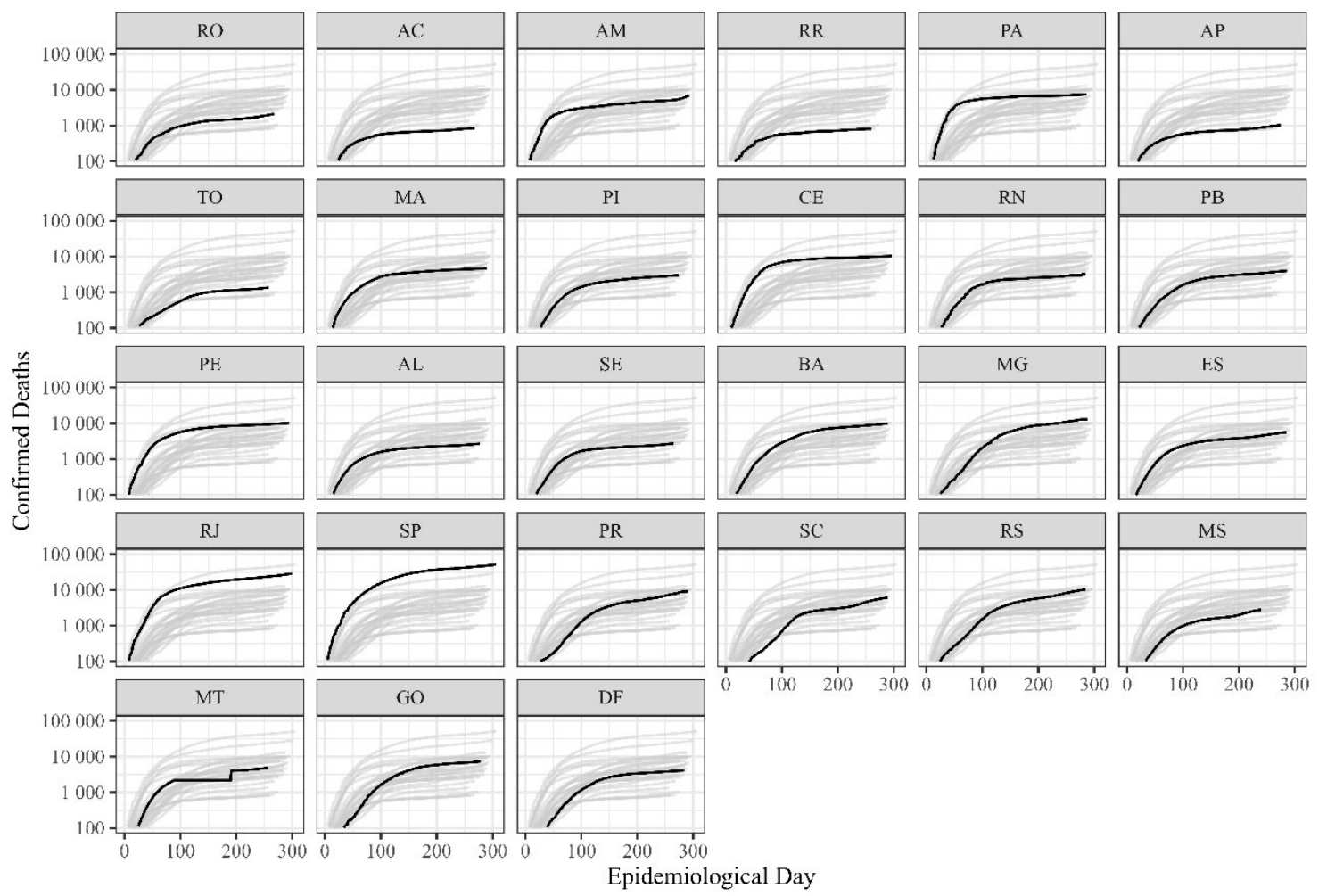

Source: The authors. 
Until the reference date, the high number of cases and deaths in SP and RJ is attributed to the fact that these states are home to the main metropolises in the country. Both the state of $\mathrm{CE}$ (shortest air link between Brazil and Europe) and PE exercise a role of regional intermediation between the northeast region and the national territory (REGIC, 2018). This factor stimulates the flow's concentration in their respective metropolises and regional capitals. Such aspects may have contributed to the high number of notifications and deaths.

In the specific case of $\mathrm{PA}$ and AM, despite not being at the top of the death ranking, these states are responsible for the connection of the northern region with the others Brazilian states, being the only ones that present urban centers in the metropolis category, presenting networks that polarize the entire region. In the interval of 100 days the behavior of these two states presents a pattern similar to those of SP and RJ, especially when the first 50 days of the series is observed. In the specific case of AM, the graph highlights the resumption of growth at the end of series, which cannot be monitored due to the time-frame of the study. National news coverage reported the gravity of the situation in January 2021, with the collapse of the capacity to serve the population. It should be taken into consideration that the ICU beds are concentrated in the capital Manaus, and given the nature of its urban network, with small cities distant from each other and a slow and predominantly waterway transport system, it helps to understand the seriousness of the situation observed in that metropolis.

\section{Socioeconomic indicators and the progression of COVID-19}

By crossing data from the PCA with the number of cases and deaths due to COVID-19 (Figure 7), until the reference date an average social vulnerability index (SVI) of 0.326 was observed. This value characterizes Brazil with average social vulnerability, and represents a reduction of $26.9 \%$ when compared to data from (IBGE, 2019), where the average SVI in Brazil was 0.446 (high social vulnerability). An analysis from the Brazilian macro-regions revealed that the north, with 0.443 , and the north-east, with 0.414 , still had high SVI; by contrast, the south (0.233), south-east (0.302) and mid-west (0.308) regions had lower rates.

Figure 7 - Characterization of the Brazilian state's social vulnerability, based on the number of notifications and deaths due to COVID-19.

Cases per $100 \mathrm{k}$

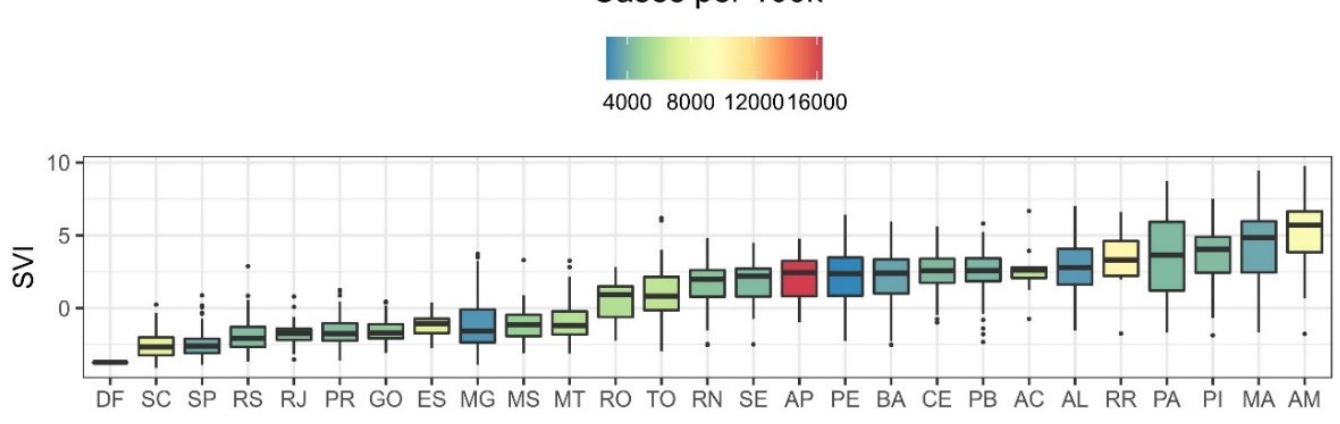

Deaths per $100 \mathrm{k}$

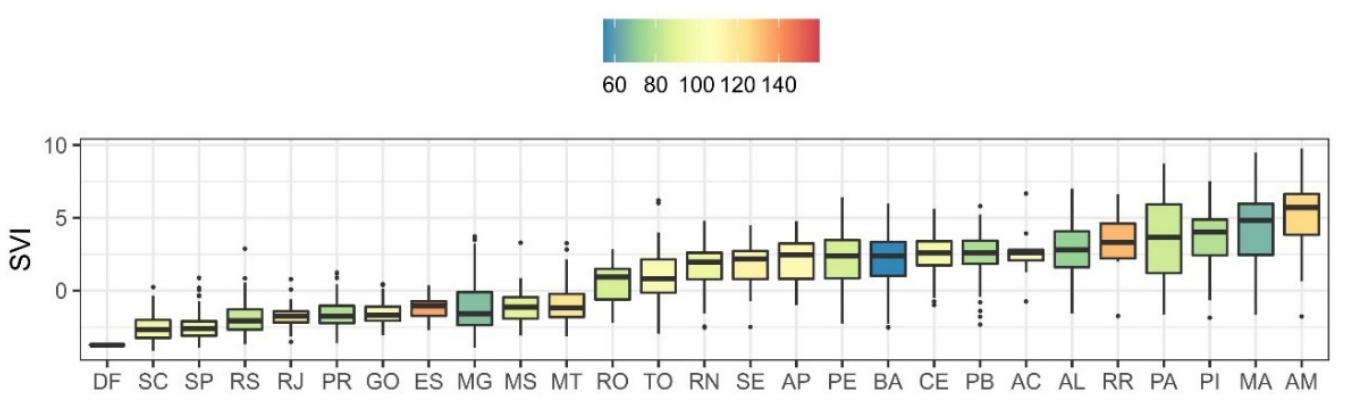

Source: The authors.

In general, there is a reasonable association between poverty and social vulnerability, and the spread and lethality of COVID-19 in Brazil.
The states of the north and north-eastern regions occupy the last positions when crossing vulnerability indicators with deaths, while the 
states of the south, south-east, and mid-west occupy the best positions. More than a third of the Brazilian states with high social vulnerability appear in a critical situation in relation to the lethality of COVID-19. When analyzing the 11 better ranked states in Figure 7 , it was possible to observe that only Rio de Janeiro (RJ) and Espírito Santo (ES) has a high lethality, higher than 100 deaths per hundred thousand inhabitants. In contrast, of the 16 states with the worst numbers in terms of social vulnerability, six have a lethality of more than 100 deaths per 100,000 inhabitants, located in the northern (AM, PA, RR and AP) and northeastern (CE and $\mathrm{PE})$ regions.

Although it is not the only affecting variable, SVI emerges as an alert, as it is an aggregated composition of variables expressing the social vulnerability of Brazilian states. States with a higher SVI tend to have more critical situations, due to the lack of urban basic sanitation and housing infrastructure, precarious public transport and, especially, the deficiencies in the public health system, which are essential elements to minimize the effects of the pandemic. The data set suggests taking local specificities and needs into account, as each region of the country has a different social reality.

Analyzing the data set by metropolitan regions (Figure 8), it was observed until the reference date that interregional inequalities in terms of social vulnerability do not change when compared to data by states. The metropolitan regions (MR) of the north and north-east continue to stand out with the highest social vulnerability, unlike the MRs of the center and south of the country. Manaus (AM) in the north region, and the large capitals of the north-east (PE - MR Recife and CE - MR Fortaleza) exhibit substantially worse numbers in terms of dissemination and deaths due to COVID-19. Aracaju (SE), a medium capital of the northeast, revealed a higher SVI and number of deaths. At the opposite extreme there are the capitals of the south and south-east (RS - MR Porto Alegre, PR - MR Curitiba, and MG - MR Belo Horizonte), where the SVI is lower. The comparative exceptions are RJ - MR Rio de Janeiro and SP - MR São Paulo, the largest metropolitan regions in Brazil, with high demographic density and extensive peripheral areas and slums.

Figure 8 - Characterization of the Brazilian social vulnerability in metropolitan regions, based on the number of notified cases and deaths due to COVID-19.

Cases per $100 \mathrm{k}$
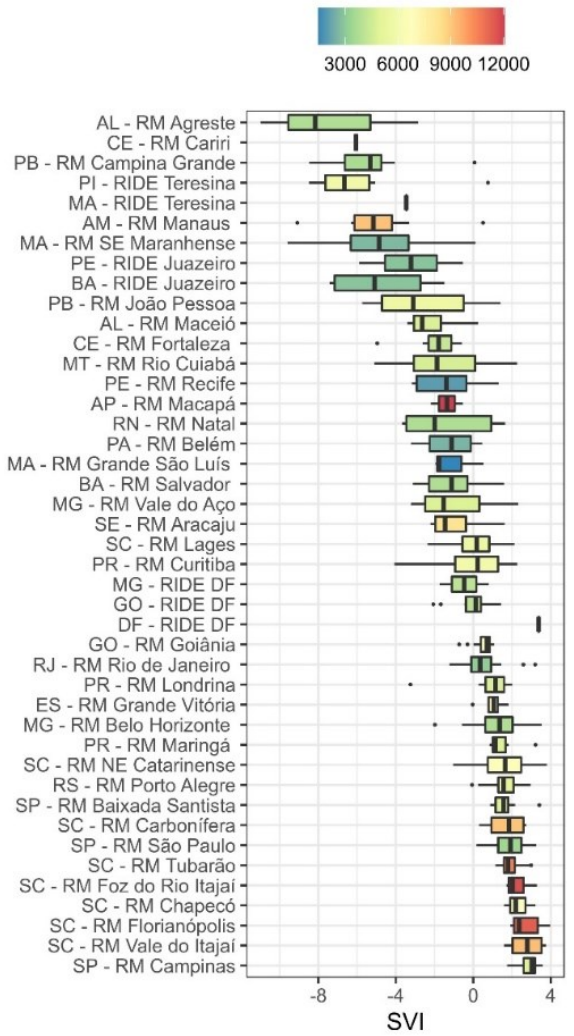

Deaths per $100 \mathrm{k}$
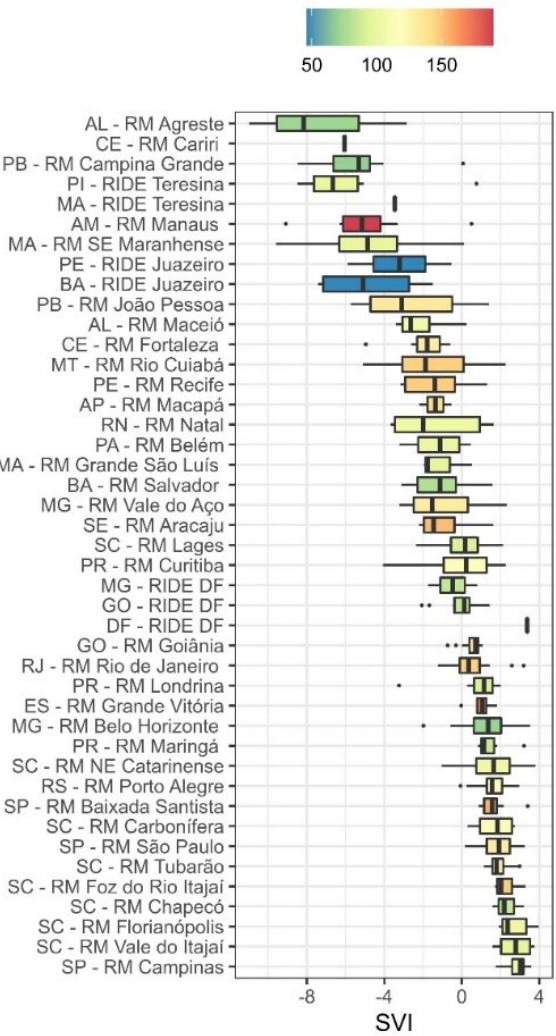

Source: The authors. 
Although COVID-19 numbers have different explanations, which include cultural factors, social distancing, urban, road and airway mobility (DE PAULA et al., 2020), demographic density, among others, it is possible to indicate social vulnerability as one of the significant variables in this process. When comparing, for example, the MRs of Salvador, Fortaleza, and Recife, which have equivalent characteristics (the coastal capitals of the northeast, with similar population, international airport hubs, with urban characteristics, and similar road networks), it is clear that death due to COVID19 is harsher in the MRs of Fortaleza and Recife, where the SVI is higher than in the MR of Salvador.

Despite the existence of quality urban infrastructure and a broader network of health services in the two largest cities in the country, it indicates that extreme poverty added to a high population density and the frantic pace of intra-urban flows in these cities, are aggravating factors with respect to the lethality of the disease. Even with a high number of ICUs compared to the cities of the north and northeast, MR São Paulo and MR Rio de Janeiro managed to collapse their health systems, crowding hospitals, and leaving patients waiting for beds and tests.

It is worth highlighting that until the reference date, the situation of Florianópolis, metropolitan region with the lowest social vulnerability index in the country, had emerged as the one of the least affected by the pandemic of COVID-19. Although it is a smaller city than the others mentioned, it is an interesting correlation, and a reference to it cannot be omitted. Despite its size, Florianópolis is a tourist city, which received a large number of visitors, increasing the possibility of spreading the disease. Other metropolitan regions with low SVI also have less critical numbers for COVID-19, such as Chapecó and Vale do Itajaí, Santa Catarina state, Campinas (SP), which, for example, despite the geographical proximity to São Paulo, is a positive highlight when compared to the other metropolitan regions.

\section{FINAL CONSIDERATIONS}

The Brazilian territory, of continental dimensions and uneven territorial cuts, is marked by a favorable space for the spread of the coronavirus. The study concluded that the airway mode, represented by international and domestic airports that establish regional connections, was considered the main vector of entrance for COVID-19 in Brazil. In this perspective, the strata of the higher income population, associated with international travel, were considered the first carriers of the virus.

The sample period indicated that the transmission process of COVID-19 to the poorer populations living in metropolitan areas happened through diversified modes. Territorial networks and urban typologies served as indicators of the areas with a greater potential for the spread of COVID-19. Intense regional economic exchanges, materialized by the inland transport of assets and passengers, industrial concentrations and the respective mobility and concentration of workers, as well as interurban traffic of people searching for trade and services in the centers of higher hierarchy, raise the level of risk of large and medium-sized Brazilian cities.

Regarding the number of confirmed cases and deaths due to COVID-19, it was observed that in absolute terms, the states of São Paulo and Rio de Janeiro had the highest numbers, which reinforces the thesis presented in the previous paragraph. When viewed through the spectrum of the social vulnerability index, the largest number of notifications and deaths were concentrated in the north and north-eastern regions of the country. The exception was Rio de Janeiro, which also has a high lethality, exceeding 100 deaths per hundred thousand inhabitants. When an analysis of metropolitan regions was carried out, it was observed that in terms of the social vulnerability index, the MRs located in the north and north-east follow the same pattern as the analysis of the states in terms of cases and deaths.

In metropolises such as São Paulo and Rio de Janeiro, where the networks are better equipped to manage the territory, there is a greater number of houses in precarious conditions in the peripheries, and it is here that the virus spread more intensely. As for the regions, both the north, in which the only access to many cities is by air and river, and northeast, the economic oblivion regarding the other regions reflects the lack of investments in health, which harms the pandemic situation by the social aggravating factor. In the case of the northern region, a rarefied urban network, where local urban centers connect directly to regional or national capitals (without the presence of intermediate centers) intensifies the concentration flows, increasing the risk of 
contagion and making it difficult by delaying patients' care (see the alarming case of Manaus). In the case of the mid-western region, the spread of COVID-19 followed the fluxes of the economy linked to agribusiness and, as in other regions, it reached regional centers with greater prominence. In the southern region, metropolises and emerging centers of integration with the south-east are the most affected, also revealing the importance of regional economic flows and dynamism as a risk factor for contamination.

An overview of the socio-economic indicators has revealed that coronavirus is reaching the economically excluded and socially marginalized groups with greater speed (informal workers, slum and periphery residents, black population, domestic workers, especially women). When verifying the data of the Brazilian social structure, an unequal distribution of income was observed, which alludes to a huge gap between the richest sections of the population and the poorest, who survive with insufficient income for primary needs and little access to services such as basic health, education, transportation, sanitation, and social protection.

Finally, as the virus does not strike everyone in the same way, one of the greatest challenges in Brazil is to search for solutions to cope with COVID-19 in the face of very unequal realities. Thus, a reflection of the strategies adopted by the Brazilian government is relevant, taking into account the continental dimensions and the diversity of the Brazilian regions to obtain a better analysis of the more vulnerable populations and social groups.

\section{ACKNOWLEDGMENTS}

The authors thanks to Álvaro Justen and Barisl.io team for compiling and making available state epidemiological bulletins. We would like to thank Editage (www.editage.com) for English language editing.

\section{REFERENCES}

ABDI, H.; WILLIAMS, L. J. Principal component analysis. Wiley Interdisciplinary Reviews: Computational Statistics, v. 2, n. 4, p. 433-459, $2010 . \quad$ Available in: https://doi.org/10.1002/wics.101

ALEIXO, N. C. R. et al. Pelos caminhos das águas: a mobilidade e evolução da COVID-19 no estado do Amazonas. Confins, n. 45, 2020. Available in: https://doi.org/10.4000/confins.30072

BERNARDES, J. A.; ARRUZZO, R. C.; MONTEIRO, D. M. L. V. GEOGRAFIA E COVID-19: NEOLIBERALISMO, VULNERABILIDADES E LUTA PELA VIDA. Revista Tamoios, v. 16, n. 1, 2020. Available in: https://doi.org/10.12957/tamoios.2020.50645

BROWNE, A. et al. The roles of transportation and transportation hubs in the propagation of influenza and coronaviruses: a systematic review. Journal of Travel Medicine, v. 23, n. 1, 2016. Available in: https://doi.org/10.1093/jtm/tav002

CANDIDO, D. et al. Routes for COVID-19 importation in Brazil. Journal of Travel Medicine, v. 27, n. 3, p. 1-3, 2020. Available in: https://doi.org/10.1093/jtm/taaa042

DATASUS, Ministério da Saúde. Painel Coronavírus (COVID-19) - Brasil. Brasília, 2021. Available in: https://covid.saude.gov.br/.

DE PAULA, D. P. et al. Diffusion of Covid-19 in the Northern Metropolis in Northeast Brazil: territorial dynamics and risks associated with Social Vulnerability. Sociedade \& Natureza, v. 32, n. September, p. 639-656, 2020. Available in: https://doi.org/10.14393/sn-v32-2020-56098

DO CARMO, M. E.; GUIZARDI, F. L. O conceito de vulnerabilidade e seus sentidos para as políticas públicas de saúde e assistência social. Cadernos de Saude Publica, v. 34, n. 3, 2018. Available in: https://doi.org/10.1590/0102-311X00101417

FATEMI, F. et al. Social vulnerability indicators in disasters: Findings from a systematic review. International Journal of Disaster Risk Reduction, v. 22, n. September 2016, p. 219-227, 2017. Available in: https://doi.org/10.1016/j.ijdrr.2016.09.006

FORSTER, P. et al. Phylogenetic network analysis of SARS-CoV-2 genomes. Proceedings of the National Academy of Sciences of the United States of America, v. 117, n. 17, p. 9241-9243, 2020. Available in: https://doi.org/10.1073/pnas.2004999117

GUIMARÃES, R. B. et al. O raciocinio geografico e as chaves de leitura da Covid-19 no territorio brasileiro. Estudos Avancados, v. 34, n. 99, p. 119-140, 2020. Available in: https://doi.org/10.1590/S01034014.2020.3499.008

HAMID, S.; MIR, M. Y.; ROHELA, G. K. Novel coronavirus disease (COVID-19): a pandemic (epidemiology, pathogenesis and potential therapeutics). New Microbes and New Infections, v. 35, p. 100679, 2020. Available in: https://doi.org/10.1016/j.nmni.2020.100679

IBGE. Sinopse do Censo Demográfi co 2010. Rio de Janeiro, 2010. Available in: https://biblioteca.ibge.gov.br/visualizacao/livros/li v49230.pdf.

IBGE. Síntese de indicadores sociais: uma análise das condições de vida da população brasileira: 2019. Rio de Janeiro: IBGE, 2019. $E$ book. 
IPEA. Atlas da vulnerabilidade social nos municípios brasileiros. Brasília: IPEA, 2015. E-book. Available in: http://ivs.ipea.gov.br/images/publicacoes/Ivs/publ icacao_atlas_ivs.pdf

JESUS, J. G. et al. Importation and early local transmission of COVID-19 in Brazil, 2020. Revista do Instituto de Medicina Tropical de São Paulo, v. 62, n. April, p. 1-5, 2020. Available in: https://doi.org/10.1590/s1678-9946202062030

KRAEMER, M. U. G. et al. The effect of human mobility and control measures on the COVID-19 epidemic in China. Science, v. 368, n. 6490, p. 493-497, 2020. Available in: https://doi.org/10.1126/science.abb4218

MOREIRA, R. A Formação espacial brasileira: contribuíção crítica aos fundamentos espaciais da geografia do Brasil. Rio de Janeiro: Ed. Consequência, 2014.

MTUR, Ministério do Turismo. Estatísticas básicas de turismo Brasil - Ano base 2018. Brasília, 2019.

REGIC. Regiões de influência das cidades : 2018 / IBGE, Coordenação de Geografia. Rio de Janeiro: IBGE, 2018. E-book. Available in: https://biblioteca.ibge.gov.br/visualizacao/livros/li v101728.pdf

REIS, C. et al. A produção do conhecimento sobre risco e vulnerabilidade social como sustentação das práticas em políticas públicas. Estudos de Psicologia (Campinas), v. 31, n. 4, p. 583-593, 2014. Available in: https://doi.org/10.1590/0103166x2014000400012

RODRIGUEZ-MORALES, A. J. et al. COVID-19 in Latin America: The implications of the first confirmed case in Brazil. Travel Medicine and Infectious Disease, v. 35, 2020. Available in: https://doi.org/10.1016/j.tmaid.2020.101613

SANTOS, J. A. F. Covid-19, causas fundamentais,classe social e território. Trabalho, Educação e Saúde, v. 18, n. 3, 2020. Available in: https://doi.org/10.1590/1981-7746sol00280

SANTOS, M. O retorno do territorio. OSAL: Observatorio Social de América Latina, v. 6, n. 16 , p. 1515-3282, 2005. Available in: http://www.clacso.org.ar/biblioteca

SILVEIRA, M. R. et al. Novo coronavírus (Sars-CoV2): difusão espacial e outro patamar para a socialização dos investimentos no Brasil. Revista Brasileira de Estudos Urbanos e Regionais, v.22, E202024pt, p. 1-36, 2020. Available in: https://doi.org/10.22296/2317-

1529.rbeur.202024pt

SOHRABI, C. et al. World Health Organization declares global emergency: A review of the 2019 novel coronavirus (COVID-19). Elsevier Ltd, 2020. Disponível em: https://doi.org/10.1016/j.ijsu.2020.02.034

SOURIS, M. Epidemiology and geography: principles, methods and tools of spatial analysis. London: ISTE Wiley, 2019. E-book. Available in: www.iste.co.uk

TAVARES, A. O. et al. Decennial comparison of changes in social vulnerability: A municipal analysis in support of risk management. International Journal of Disaster Risk Reduction, v. 31, n. July, p. 679-690, 2018. Available

in: https://doi.org/10.1016/j.ijdrr.2018.07.009

WHO. Covid-19 weekely epidemiological update. Situation report 24 january 2021. https://covid19.who.int/

\section{AUTHORS' CONTRIBUTION}

Miguel da Guia Albuquerque supervised the study, wrote and revised the text. Jefferson Rodrigues dos Santos analized the sociodemographic and infrastrusture data, and revised the text. Angelita Fialho Silveira analized the socioeconimic indicators and Covid-19 evolution data and revised the text. Dardo Lorenzo Bornia Junior analized the socioeconimic indicators and Covid-19 evolution data and revised the text. Rozele Borges Nunes analized the sociodemographic and infrastrusture data, and revised the text. Tiago Borges Ribeiro Gandra collected, analyzed the data, elaborated the maps, and revised the methodology. André Luis Corrêa da Silva analized the data, and revised the text. Gustavo Borba de Miranda analized the data, and revised the risks and Covid-19 vulnerabilities text. Alessandra Ruiz Trevisol analized the data, and revised the risks and Covid-19 vulnerabilities text. 